\title{
Towards an asymmetry-based view of Chinese firms' technological catch-up
}

\author{
Jiang Wei, Ding Wang and Yang Liu*
}

* Correspondence:

yangliu@zju.edu.cn

School of Management, Zhejiang

University, Hangzhou 310058, China

\begin{abstract}
By carefully reviewing our research and related literature, in this paper, we propose a two-stage model of Chinese firms' technological catch-up, and provide asymmetrybased explanations. We argue that at the approaching stage, Chinese firms mainly focus on knowledge accumulation through frugal innovation for capturing local and global low-end markets; while at the pole vault stage, they focus on knowledge creation through radical innovation for capturing the high-end market. Moreover, we propose that lacking world-leading technologies but striving to achieve technological catch-up quickly, Chinese firms mainly rely on asymmetric resource and capabilities that are embedded within Chinese institutional, technological and market contexts. Turning these asymmetries into sustainable capabilities and then matching them to market opportunities by developing asymmetric innovation strategies, Chinese firms could achieve technological catch-up in a unique way.
\end{abstract}

Keywords: Technological catch-up, Asymmetry-based view, China, Innovation

\section{Introduction}

For the first time, Chinese firms occupy the 115 and 120 positions on the 2017 and 2018 Fortune Global 500 lists, respectively. ${ }^{1}$ Of these, the telecom giant Huawei, internet giants Baidu, Alibaba, and Tencent, and automobile giant Geely have started to outperform their better-known European and U.S. peers. The rise of Chinese firms raises the question of how Chinese latecomer firms could further minimize the technological and market share gaps between themselves and other leading companies on the global economic stage (Wei et al. 2016a).

The extant literature on latecomer firms "catching up" to their global competitors has mainly focused on firms from newly industrialized countries, such as South Korea (Kim 1998; Lee and Lim 2001; Mahmood and Singh 2003). For example, Kim (1997) proposes a process model to describe South Korean firms' technological catch-up, and Lee et al. (2001) identify a model of technological and market catch-up based on South Korean industries. Recently, Lee and Malerba (2017a) organized a special issue on changes in industrial leadership and successive catch-up by late entrants. The special issue illustrates an overall picture of catch-up cycles with evidence from a number of industries (e.g., Landini et al. 2017; Lee and Malerba 2017b; Morrison and Rabellotti 2017; Shin 2017; Vértesy 2017).

Acknowledging the uniqueness of China (Lee 2005; Lee et al. 2002; Lee and Malerba 2017a; 2017b), this research line provides an insightful but often incomplete picture of how Chinese firms are catching up to their global competitors. First, according to The

(c) The Author(s). 2018 Open Access This article is distributed under the terms of the Creative Commons Attribution 4.0 International License (http://creativecommons.org/licenses/by/4.0/), which permits unrestricted use, distribution, and reproduction in any medium, provided you give appropriate credit to the original author(s) and the source, provide a link to the Creative Commons license, and indicate if changes were made. 
Global Competitiveness Report 2017-2018, China's local market size ranks first in the world, far beyond newly industrialized countries such as South Korea and Singapore, which rank 13 and 35 respectively. This large but highly segmented market contains consumers with various consumption patterns and levels of purchasing power, thus providing a unique market context for Chinese latecomers to catch up (Buckley and Hashai 2014; Mu and Lee 2005). Second, China has been experiencing a fundamental and comprehensive institutional transition, which provides both constraints and support for Chinese firms' technological catch-up (Godinho and Ferreira 2012; Kafouros et al. 2015; Liu et al. 2011). Third, with relatively weak intellectual property rights (IPRs) enforcement, the technological environment also provides Chinese firms with both opportunities and constraints for catching-up. The uniqueness of China's market, institutional and technological contexts fundamentally influences Chinese firms' strategic decisions and catching-up process (Choi et al. 2011; Guo et al. 2016; Nam 2015; Rong et al. 2017; Wu 2012; Xiao et al. 2013), which cannot be explained by extant technological catch-up models of latecomer firms.

In order to fill these gaps, the first author of this paper and his research team have devoted around 20 years to study Chinese firms' unique paths to technological catch-up (e.g., Wei 2002; Wei et al. 2017; Wei et al. 2016e). In reviewing our research and related literature, this paper proposes a model of technological catch-up of Chinese firms from an asymmetry-based view. Our research contributes to the extant literature in several ways. First, by carefully reviewing our research and related literature, we propose a Chinese version of the two-stage technological catch-up model to prompt a discussion of the factors that contribute to Chinese firms' uniqueness in this regard. Second, we try to propose an asymmetry-based view which provides an underlying explanation for the unique Chinese firms' technological catch-up process. In the following sections, we first propose a two-stage model of Chinese firms' technological catch-up. We then provide some theoretical explanations for the model's operative processes from an asymmetry-based view. We conclude our paper by discussing possible future research directions.

\section{A two-stage model of Chinese firms' technological catch-up}

\section{Conditions for Chinese firms' technological catch-up}

Similar to latecomer firms in other newly industrialized countries, Chinese latecomer firms are typically characterized by a lack of key materials and technical resources, especially in terms of world-leading technologies (Kim 1997; Wei et al. 2016a). However, the conditions for Chinese firms' technological catch-up are also quite unique relative to other contexts (Wei and Liu 2017). First, China's market-the largest single market for virtually all products and services (Sheth 2011) - provides firms with great opportunities not only to survive but to grow. With a population of more than 1.3 billion, China's market is hardly homogeneous: It is highly segmented and contains consumers with various consumption patterns and levels of purchasing power (Cui and Liu 2000). For example, while Chinese consumers accounted for more than $30 \%$ of global luxury products in 2017, ${ }^{2}$ as of 2014 there were still 26 million people with less than $\$ 1.90$ in purchasing power parity per day. ${ }^{3}$ On the one hand, this large market attracts multinational companies (MNCs) to invest in China, for instance, in exporting, joint ventures, and greenfield investment. This inward foreign direct investment provides 
technological and management knowledge and spillover benefits, thus helping Chinese firms to learn and accumulate knowledge toward technological advancement (Buckley et al. 2002, 2007; Buckley and Hashai 2014). On the other hand, there is still a large, high-growth, and price-sensitive market ignored by MNCs. This provides Chinese firms a space to survive and grow (Zeschky et al. 2011). By providing products at lower costs to meet price-sensitive consumers' needs, Chinese firms not only secure capital for further investment in research and development (R\&D), but also accumulate experiential knowledge through learning-by-doing processes. In sum, China's large but segmented market provides firms with tremendous opportunities to develop a knowledge-base for technological advancement.

Second, China's institutional transition also provides firms with opportunities to survive and grow. China has been experiencing a fundamental and comprehensive transition from central planning to a market orientation since the 1978 policy reforms (Peng 2003). During this long institutional transition, both formal and informal institutions have changed gradually. For example, the legal system for protecting IPRs in China was first established in 1985, and despite having undergone several significant reforms, it is still in need of further improvement (Huang et al. 2017). Institutional voids-where sophisticated institutional infrastructure to support a market-based system is still lacking (Khanna and Palepu 1997) - thus continue to significantly influence Chinese firms' technological advancement. Moreover, the Chinese government continues to manage the access to key resources and provides institutional support to firms through resource allocation based on national strategic planning, polices, and regulations (Zhou et al. 2017), thus providing firms with opportunities to survive and grow. Liu et al. (2011) comprehensively examine 366 of China's innovation policies from 1980 to 2008. Such policies are designed "to reform the science and technology (S\&T) system, to increase investment in S\&T and the number of scientists and engineers, to establish high-tech parks, to encourage venture capital investment, to better protect IPRs, and lately to build a more innovation-oriented nation (Liu et al. 2011: p. 917)." For example, Wei et al. (2016a) find that the Chinese government could help firms achieve technological catching-up by creating an institution-led market. In addition, Chinese companies have developed unique capabilities in response to institutional uncertainty that help these firms create or discover opportunities (Liu 2017).

Third, the technological environment also provides Chinese firms with opportunities not only to survive but to grow. Some key technologies are available in the global market. With relatively weak IPRs enforcement in China, Chinese firms can imitate and innovate by combining these technological resources to fulfill local consumers' needs (Luo et al. 2011). In addition, technological clusters prevail in China. There are many small and medium enterprises which are component contractors for larger firms, and a large amount of specialized intermediaries also facilitate the learning process of these firms. Consequently, mass manufacturing with standardized technology can be achieved in these technological clusters (Wei et al. 2016g). In conclusion, the uniqueness of China's market, and institutional and technological contexts fundamentally influences Chinese firms' technological catching-up process. In the following section, we will propose a two-stage technological catch-up model to describe this unique process. 
The approaching stage: Knowledge accumulation

\section{Frugal innovation for capturing local and global low-end markets}

Figure 1 presents the overview of the "approaching stage" of Chinese firms' technological catch-up. Despite the fact that the high-end market has been dominated by MNCs, the low-end market has great potential for Chinese enterprises to develop and catch up with their MNC competitors. Without world-leading technologies, Chinese latecomer firms must first focus on providing so-called frugal innovation for the large, high-growth, and price-sensitive market. Products developed through frugal innovation often look inferior to existing solutions because they provide limited functionality and are often made of cheaper materials. By reducing costs through the process of using lower-cost raw materials, components, etc., Chinese firms develop new products with inferior functionality to their competitors', but which can be sold at a more affordable price, thus targeting local customers (Zeschky et al. 2014; Zeschky et al. 2011). For example, automobile giant Geely's first product, "Haoqing Motors," had all of the basic functions of an automobile but was sold at a dramatically lower price than other cars. Geely quickly gained favor in the Chinese market after first being listed in the China Automotive Manufacturers Product Bulletin in 2001 (Jiang et al. 2011). Telecom giant Huawei also discovered a huge opportunity in the Chinese market, especially in rural areas in the early 1990s. Combining existing mature technologies, Huawei developed a "rural digital exchange solution" that factored in the characteristics of China's rural markets. The company quickly captured a huge market share, not only in China but also worldwide, due to the low price of its product (Wei et al. 2016b).

\section{Knowledge sources for frugal innovation}

At the approaching stage, the main knowledge sources for Chinese firms' frugal innovation are technology spillovers from MNCs from advanced markets (e.g., joint ventures in China, original equipment manufacturers), research output from local and global universities, and knowledge-sharing in local clusters (Liang 2017). First, international joint ventures provide foreign partners with quick and easy access to new markets by leveraging local partners' market knowledge and local networks, helping reduce risks and increase revenue. In return, foreign partners bring technological and managerial knowledge and capital (Kim 1997). In transitional economy joint ventures, not

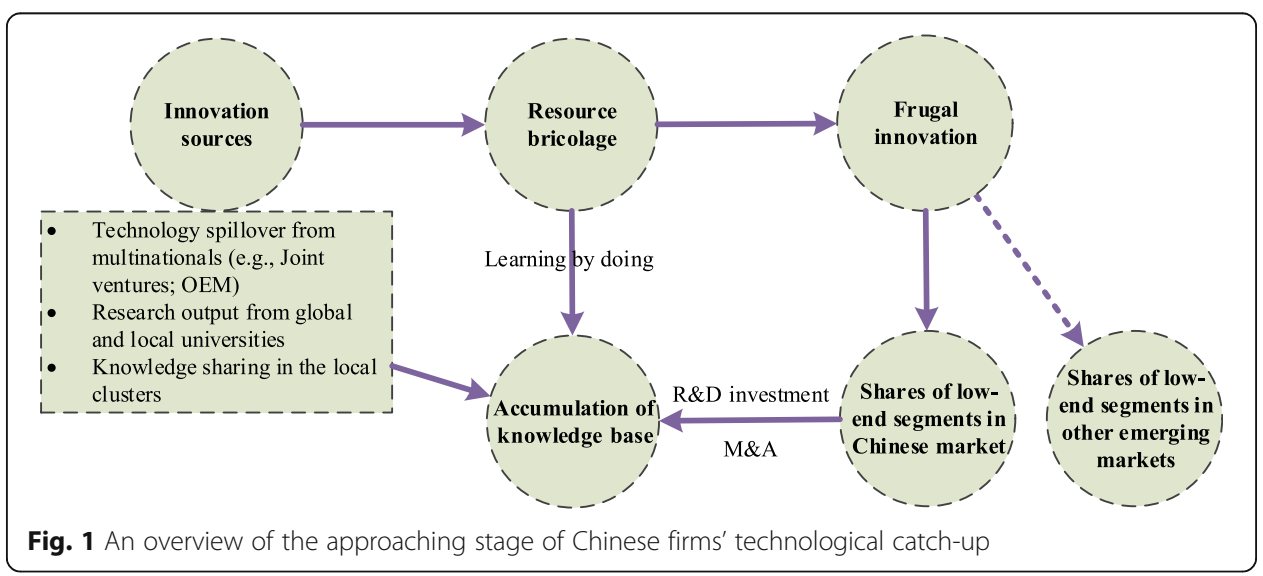


only is the knowledge that each partner brings different, so as the specific knowledge needs (Griffith et al. 2001). Second, original equipment manufacturers (OEM) have acted as training schools for latecomers, enabling them to overcome entry barriers and assimilate manufacturing and design technology (Hobday 1995). Latecomer firms also take advantage of knowledge spillover from OEM customer firms in terms of R\&D activities, such that latecomers have the opportunity to move beyond OEM and develop original design manufacturing (ODM), for instance, by engaging in product upgrading (Liu et al. 2013). Third, enterprises embedded in technological clusters can effectively absorb local knowledge through local networks, thus acquiring a unique ability to localize (Wei et al. 2016g). In a transitional economy, latecomer firms embedded in such clusters face a dilemma: While local innovation networks promote knowledge spillover through collective learning, geographical and cognitive proximity can also lead to a local lock-in effect, which leads to the decline of the cluster.

There are two ways to search for knowledge: local knowledge searching and cross-border knowledge searching (Leiponen and Helfat 2010). Latecomer firms have engaged in both strategies, thereby contributing to knowledge accumulation and product innovation (Wu and Wei 2013). By knowledge searching, latecomer firms combine the local and hyper-local together to successfully expand their knowledge base (Peng and Liu 2016). There is some disagreement among scholars on this, as to whether OEM or joint ventures contribute the most to latecomer firms' knowledge accumulation. However, it is also likely that neither approach brings core technology to latecomer firms. Indeed, latecomer firms may face a risk of being locked in at the bottom of the value chain. Given the highly unstable environment and the existing knowledge gap between local and foreign firms in the context of a transitional economy, knowledge transfer is critical. MNCs have an incentive to prevent knowledge leakage to competitors (Liang 2017) and yet simultaneously seek to exploit the low costs of production in emerging economies.

Further, although most Chinese firms do not have access to scarce resources, such as critical materials and world-leading technologies (Jiang et al. 2011; Liu et al. 2013), they have nonetheless developed skills to excavate and recombine the limited resources at hand. Frugal innovation, in this sense, may be developed through entrepreneurial bricolage, using limited resources skillfully to create something from nothing (Liu et al. 2018). Relatively weak IPRs enforcement may make this process much easier for Chinese firms. As a result, Chinese firms have lowered costs and are able to successfully satisfy the low-end market. For example, Geely did not have the technology to make cars initially. To acquire automobile manufacturing technology, Geely's chief executive provided its engineers with his own car to learn from. The engineers disassembled the car into parts to gain a deeper understanding of the details of automobile manufacturing and combined the parts from this car with technology from other companies to develop Geely's first product. During this process of "bricolage," in addition to innovating frugally, Geely accumulated technical know-how and gradually improved its technological capability.

\section{Pole vault stage: Knowledge creation}

\section{Radical innovation for capturing the high-end market}

After the "approaching stage," a large number of Chinese enterprises are able to gradually complete their accumulation of knowledge and occupy a sufficient share of 
international and domestic markets. Some of these firms have even become global leaders in their industries, such as Geely, Haier, Huawei, and others. However, the international and even domestic high-end markets are still controlled by companies from more advanced economies and Chinese innovations, in terms of sophisticated technology, remain scarce. Chinese companies are thus faced with the challenge of catching up with incumbents and acquiring industrial leadership (Fig. 2).

During the "pole vault stage," Chinese enterprises would be ill-advised to use the same strategies as they had during the approaching stage, lest the risk of falling into the trap of "catching up and falling behind" (Wei and Liu 2017). Chinese enterprises in the pole vault stage strive to create knowledge and make radical innovations to forge ahead of their incumbent competitors. Awate et al. (2015) argue that knowledge access is a significant factor for companies in transitional economies to be able to catch up with MNCs. Other scholars believe that capability building is also key, especially considering the significant role that capability plays in maintaining sustainable competitive advantages during a firm's development (Jiang et al. 2011). Chinese enterprises' catch-up strategies are essentially a process of capability building. With an accumulation of capability, latecomer firms gradually switch from imitation to innovation (Chang et al. 2006).

Certain windows of opportunity allow for the change in global leadership, from the incumbent to the latecomer, accompanied by a decline of the incumbent (Chang et al. 2006). Latecomers' successful responses to these windows of opportunity are usually associated with high levels of knowledge and learning. Only after accumulating enough knowledge and sufficiently upgrading capabilities do windows of opportunity trigger companies to forge changes in global leadership. Perez and Soete (1988) first introduce the concept of "windows of opportunity," and Lee and Malerba (2017b) extend the notion, specifying how they can be related to technology (a technological window), market conditions (a demand window), in addition to public policy and institutional settings (an institutional window).

Technology windows occur when new technology allows for radical innovation. When a new technology or radical innovation is introduced, the incumbent may fall behind if it is locked into existing technology. This situation is known as the "incumbent trap" (Chandy and Tellis 2000). The incumbent continues to invest and enhance its

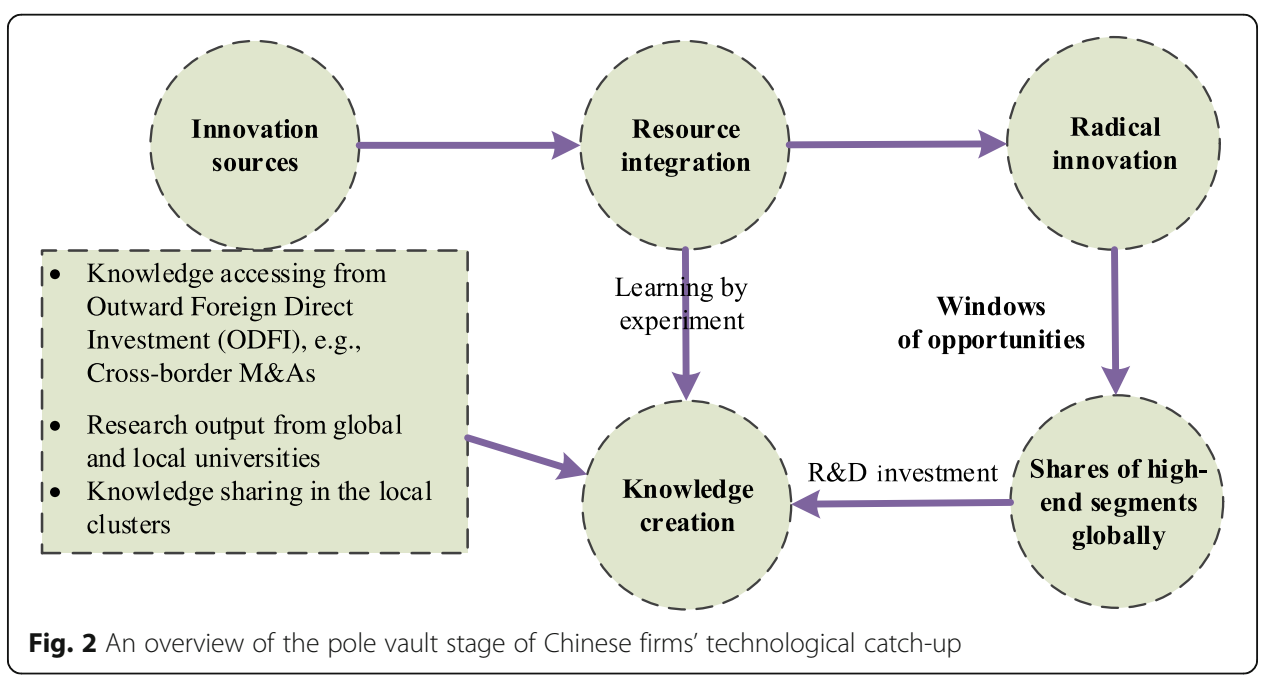


existing technology, which impedes its ability to seize opportunities arising from technological change, whereas latecomer firms can more easily and actively adopt new technologies to forge ahead. Demand windows describe the creation of new demand in a market. Unlike incumbents, latecomers have stronger motivations to respond to such new demand. If new demand grows rapidly, the effect may provide ample possibilities for late entrants to catch up (Lee and Malerba 2017b). Institutional windows of opportunity describe government intervention through public policies or institutional change. In certain instances, institutional support in emerging markets can be the only source of market creation and support for local firms (Wei et al. 2016c). By capturing these windows of opportunities, Chinese firms have the potential to capture huge market shares, both domestically and globally.

These concepts suggest that latecomer firms should move beyond imitation and focus on radical innovation if they want to be able to "catch up," rather than merely "keep up," with incumbents (Hobday 1995). A large number of studies have focused on knowledge searching, technological learning, and technological capability development (Cho et al. 1998; Hobday 1995; Kim 1998; Mathews and Cho 1999). As latecomer firms approach technological frontiers, incumbent firms in developed countries are more reluctant to share their technology; the technology itself is also increasingly complex (Chang et al. 2006). These challenges will make it much more difficult for latecomer firms to absorb knowledge spillover from firms in developed countries. To catch up with incumbents, then, latecomer firms need to leverage their existing knowledge base and capabilities to achieve radical innovation and create new knowledge.

\section{Knowledge sources for radical innovation}

As competition becomes more technology-intensive and sources of knowledge get more dispersed, latecomer companies must utilize and acquire knowledge from various sources to boost their own knowledge base. Considering the lack of market and technical resources for latecomer enterprises (Hobday 1995), companies are likely to find it difficult to compete internationally with only firm-specific knowledge generated through internal R\&D (Luo and Wang 2012). Chinese companies that rely too heavily on local knowledge may even fall into the so-called "local lock-in" trap, in which previously learned knowledge and selected patterns of behavior are preserved to a degree that new alternatives are prohibitive. Latecomer firms should not only utilize internal research to develop their knowledge and enhance their innovation capabilities but also expand R\&D networks across organizational and geographical boundaries in order to search for and integrate knowledge within global networks (Liu et al. 2013). In this light, scholars have begun to explore a variety of sources of knowledge, including cross-border M\&As (Deng 2009; Deng et al. 2018), cooperation with universities (Wei et al. 2017), the establishment of subsidiaries or R\&D centers overseas (Wei et al. 2014a, 2014b), and the construction of asymmetrical alliances with competitors, universities and public R\&D institutes (Liu et al. 2017). With such strategizing, some Chinese companies have been able to make acquisitions in developed economies directly (Madhok and Keyhani 2012; Wei et al. 2016f; Wei and Wang 2017), enabling themselves to gain access to different national innovation systems. By integrating these different knowledge sources, Chinese firms could develop radical innovations for capturing high-end segments globally. 


\section{An asymmetry-based view of Chinese firms' technological catch-up}

\section{An asymmetry-based view}

Miller (2003) proposes the notion of "the asymmetry-based view" by systematically questioning the resource-based view. Theorists of the resource-based view hold that competitive advantages can only be earned from valuable, rare, inimitable, and non-substitutable resources. But as Miller (2003: p. 962) asks, "How can companies that do not already have such resources create them?" He argues that companies could rely on asymmetric resources or capabilities that are "inimitable differences between themselves and other firms that in their initial states could in no way be considered valuable" (Miller 2003: p. 963). By identifying such asymmetries, turning them into capabilities and matching those to market opportunities, firms can generate sustainable capabilities (Miller 2003) (Fig. 3).

This "sustainability-attainability dilemma," as Miller (2003) calls it, is exactly the dilemma that Chinese firms face, as they lack world-leading technologies but strive to achieve technological catch-up quickly. In fact, most Chinese firms do not monopolize firm-specific resources, typically advanced technologies or brands. Some start with a little and end with a lot. Due to the distinct relations between developing and developed countries, Chinese firms confront different kinds of problems and resolve them in different, and often innovative, ways. Therefore, by implementing an asymmetry-based view, researchers can shift focus from advantages (and already-advantageous resources) to asymmetries as a starting point, gaining a deeper understanding of latecomers' unique capabilities and strategies and using the emerging-economy context for theory development (Wei et al. 2017). For example, Madhok et al. (2012) suggest that the spirit of the asymmetry-based view is in seeing potential where it has not yet been realized and identifying "assets of emergingness" embedded within the emerging-economy context. We thus propose an asymmetry-based view of Chinese firms' technological catch-up to better understand how Chinese latecomer firms can discover and reconceptualize asymmetries and turn them into competitive advantages to achieve technological catch-up.

Building on Miller's (2003) work, we argue that Chinese firms' asymmetric resources and capabilities are embedded within Chinese institutional, technological, and market contexts. After identifying and reconceptualizing the asymmetric resources, Chinese firms could turn these asymmetries into capabilities by strategically embedding them within their organizational context. Finally, Chinese firms need to match these asymmetric capabilities to market opportunities by developing asymmetric innovation strategies.

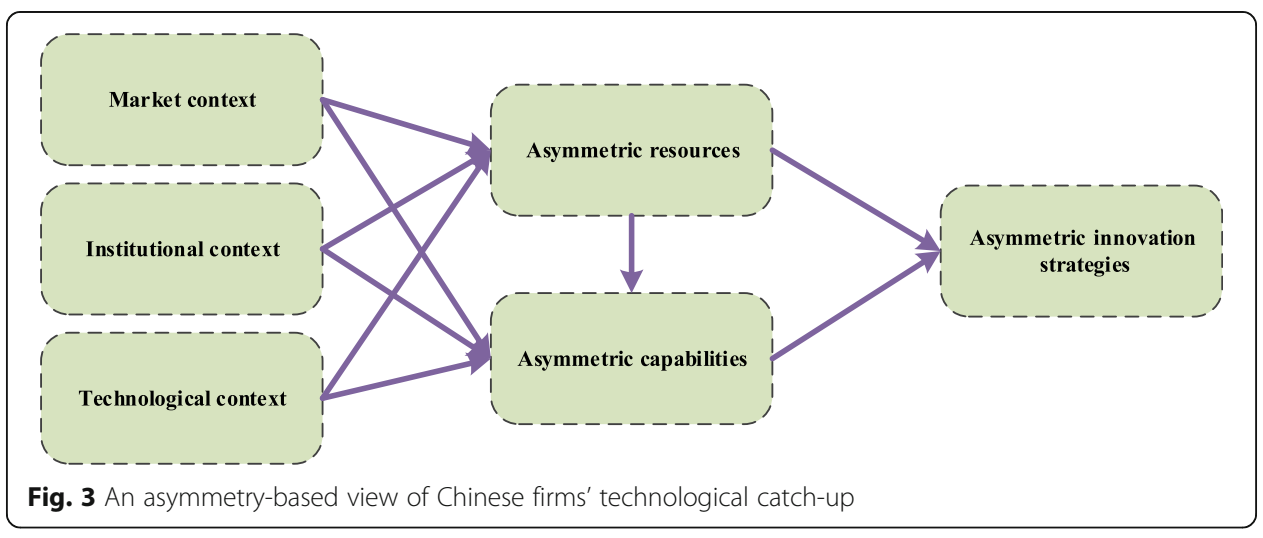




\section{Asymmetric resources and capabilities for Chinese firms}

We define asymmetric resources and capabilities for Chinese firms as rare and inimitable skills, processes, and assets that foreign competitors do not have and that are not yet connected to value creation for the Chinese firm. Asymmetric resources for Chinese firms originate in the market from the technological, and institutional contexts that shape the formation of these firms (Madhok et al. 2012). By identifying such resources and embedding them within their organizational contexts, Chinese firms can develop competitive advantages (Wei and Liu 2017). As shown in the approaching stage of Chinese firms' technological catch-up, institutional voids and supports, along with the potential of a large, high-growth, and price-sensitive markets, provide Chinese firms with ample opportunities to identify asymmetric resources.

For example, institutional voids in emerging economies impede the development and flow of resources, constraining economic opportunities by creating social, regulatory, and political uncertainties (Khanna and Palepu 1997). However, different from other Asian emerging countries, the Chinese government is extremely powerful, as it possesses abundant key resources to drive firms' innovation. The Chinese government drives and manages innovation by controlling and distributing key resources, even creating "institution-led markets," such as the Chinese video surveillance industry, which is boosted by "Intelligent City" and "Safe China" policies. Hikvision, a Chinese firm in the video surveillance industry, has benefited tremendously from government procurement and support in innovation resource, including human capital, funding, and platform resources.

Another typical case is about Chinese internet companies. When China's internet industry was still in its infancy, the internet-related institutional system was undeveloped and inadequate. Internet firms such as Alibaba, Baidu and Tencent took advantages of China's institutional voids and obtained a golden development opportunity through institutional entrepreneurship. In the process of development, China's internet firms were faced with fewer institutional constraints, and developed asymmetry capabilities to carry out technological and business model innovation. As a result, these firms have grown into industry giants. Typical examples of Chinese firms' asymmetric capabilities, in these cases are what have been called institutional leverage capabilities-the "capacity to identify local institutional benefits, establish and maintain the legitimacy to engage with the institutions, purposefully interact with them, and to configure its existing resources in such a way as to integrate institutional benefits for achieving its desired ends (Landau et al. 2016: p. 54)."

\section{Asymmetric innovation strategies for Chinese firms}

We define asymmetric innovation strategies as the reflection of a Chinese firm's unique commitment to developing and marketing products that are new to the firm and/or the market. Asymmetric resources and capabilities alone do not guarantee that Chinese latecomers can catch up with incumbents if proper strategies are not developed to utilize and leverage those resources and capabilities efficiently. If latecomers merely imitate incumbents' strategies, they are likely to remain followers. Matching asymmetric capabilities to market opportunities through asymmetric innovation strategies can thus aid Chinese latecomers to leverage existing resources and capabilities, and forge ahead of their international competitors. 
In fact, with technological development and transformations in the technological paradigm, Chinese firms tend to be less path-dependent and more adept at learning. Because of discontinuities in technological trajectories, latecomer firms can exploit a leapfrog strategy and take advantage of the new paradigm to overtake the incumbent. Some development stages can easily be skipped to access the latest technologies directly. Moreover, companies can create their own individual paths differ from the incumbent's.

As evidence in the review of the approaching stage, China has an incredible market space characterized both by opportunity and by imbalance and instability. New demands, which are heterogeneous and personal, are continually popping up in the Chinese market. Most Chinese firms thus adopt a frugal innovation strategy for knowledge accumulation. For example, in the ICT industry, unlike incumbent firms such as Ericsson and Samsung, the Chinese firm Huawei has implemented an asymmetry-driven innovation strategy. Instead of entering the mainstream market, Huawei aimed to meet the needs of a far less developed market and at lower costs, thereby avoiding direct competition with incumbent companies.

\section{Discussion and conclusion}

We began by noting that Chinese firms' technological catch-up process is unique. By carefully reviewing our research and related literature, in this paper, we have proposed a two-stage model of Chinese firms' technological catch-up, and provided an asymmetry-based explanation. We find that at the approaching stage, Chinese firms mainly focus on knowledge accumulation through frugal innovation to capture local and global low-end markets. At the approaching stage, the main knowledge sources for Chinese firms' frugal innovation are technology spillovers from MNCs from advanced markets, research output from local and global universities, and knowledge-sharing in local clusters. As well, resource bricolage capability is important for Chinese firms' frugal innovation output, and also knowledge accumulation. At the pole vault stage, Chinese firms mainly focus on knowledge creation through radical innovation to capture the high-end market. Chinese firms need to utilize and acquire knowledge through various sources (e.g., cross-border M\&A) to boost their own knowledge base, and resource integration capability is important for their radical innovation and also for knowledge creation.

Moreover, we argue that, lacking world-leading technologies but striving to achieve technological catch-up quickly, Chinese firms thus rely on asymmetric resources and capabilities that are "inimitable differences between themselves and other firms that in their initial states could in no way be considered valuable" (Miller 2003: p. 963). By reconceptualizing these asymmetric resources that are embedded within Chinese institutional and market contexts, Chinese firms could turn these asymmetries into capabilities and then match them to market opportunities by developing asymmetric innovation strategies. Especially in the context of a China-US trade war, developed countries are imposing ever more severe blockades and sanctions on China in frontier technologies, such as IC chips, new materials, and pharmaceuticals. Chinese firms are faced with great challenges in getting access to knowledge abroad. Since there is a large gap between Chinese technology development and that of developed countries, Chinese firms need to adopt asymmetric catch-up strategies to exploit their own advantages and put effort into critical technological areas. We thus provide an underlying explanation for the unique technological catch-up process of Chinese firms. From an asymmetry- based view, we suggest scholars 
and Chinese managers should shift their attention from disadvantages to asymmetries. Although some asymmetric resources embedded in the institutional, technological, and market contexts may be disadvantages, and act as liabilities in their current form, they have the potential to be turned into sustainable capabilities.

Our research, however, is preliminary and there is much room for future research. First, more studies are needed to identify the asymmetric resources of Chinese firms. We have argued that asymmetric resources are embedded within Chinese institutional, technological, and market contexts. Future research should pay more attention to Chinese unique contexts that may stimulate Chinese firms to identify asymmetric resources and turn them into sustainable capabilities. For example, more research is needed to explore the roles of IPRs protection in facilitating the technological catch-up of Chinese firms. Moreover, many scholars have studied the effect of formal regulations and policies of emerging economies on latecomer firms' catch-up strategies (Lee and Malerba 2017b), but informal institutions have been largely ignored. Future research may focus on identifying asymmetric resources embedded in informal institutions (e.g., Taoism, Confucianism). Second, future research should pay more attention to how to turn asymmetric resources into Chinese firms' competitive advantages. Identifying the asymmetries of latecomer firms is just a beginning. More research is needed to explore how Chinese firms could turn these asymmetries into capabilities and then match them to market opportunities for achieving technological catch-up. Third, we have just provided the definition of a construct of asymmetric innovation strategy and illustrated it with some examples. More research is needed to explore its dimensions as well as antecedents and consequences. Last but not least, more generally, further exploring the role of technological catch-up in supporting the leadership of China in the global arena in the next decades will provide important theoretical and practical implications.

\section{Endnotes}

${ }^{1}$ Fortune, 2018. http://fortune.com/fortune500/. Accessed on 2018.7.20.

${ }^{2}$ Bain \& Company: http://www.bain.cn/pdfs/201801170740528448.pdf. Accessed on 2018.3.21.

${ }^{3}$ Asian Development Bank: https://www.adb.org/sites/default/files/publication/298061/ basic-statistics-2017.pdf. Accessed on 2018.3.21.

Acknowledgements

We would like to thank the editor and both reviewers for their insightful comments on the paper. Constructive suggestions from co-learners are also appreciated.

Funding

The study was funded by the Key Program of the National Natural Science Foundation of China (No. 71732008) and National Natural Science Foundation of China (No. 71872161; 71874150).

Availability of data and materials

Data sharing not applicable to this article as no datasets were generated or analyzed during the current study.

Authors' contributions

All authors contribute equally to the paper. All authors read and approved the final manuscript.

Authors' information

Jiang Wei is a professor at School of Management, Zhejiang University. Ding Wang is a PhD candidate at School of Management, Zhejiang University. Yang Liu is a ZJU-100-Young professor at School of Management, Zhejiang University. 


\section{Publisher's Note}

Springer Nature remains neutral with regard to jurisdictional claims in published maps and institutional affiliations.

\section{Received: 25 July 2018 Accepted: 10 October 2018}

Published online: 06 November 2018

\section{References}

Awate, S., Larsen, M. M., \& Mudambi, R. (2015). Accessing vs sourcing knowledge: A comparative study of R\&D internationalization between emerging and advanced economy firms. Journal of International Business Studies, 46(1), 63-86.

Buckley, P. J., Clegg, J., \& Wang, C. (2002). The impact of inward FDI on the performance of Chinese manufacturing firms. Journal of International Business Studies, 33(4), 637-655.

Buckley, P. J., Clegg, J., \& Wang, C. (2007). Is the relationship between inward FDI and spillover effects linear? An empirical examination of the case of China. Journal of International Business Studies, 38(3), 447-459.

Buckley, P. J., \& Hashai, N. (2014). The role of technological catch up and domestic market growth in the genesis of emerging country based multinationals. Research Policy, 43(2), 423-437.

Chandy, R. K., \& Tellis, G. J. (2000). The incumbent's curse? Incumbency, size, and radical product innovation. Journal of Marketing, 64(3), 1-17.

Chang, S. J., Chung, C. N., \& Mahmood, I. P. (2006). When and how does business group affiliation promote firm innovation? A tale of two emerging economies. Organization Science, 17(5), 637-656.

Cho, D. S., Kim, D. J., \& Dong, K. R. (1998). Latecomer strategies: Evidence from the semiconductor industry in Japan and Korea. Organization Science, 9(4), 489-505.

Choi, S. B., Lee, S. H., \& Williams, C. (2011). Ownership and firm innovation in a transition economy: Evidence from China. Research Policy, 40(3), 441-452.

Cui, G., \& Liu, Q. (2000). Regional market segments of China: opportunities and barriers in a big emerging market. Journal of Consumer Marketing, 17(1), 55-72.

Deng, P. (2009). Why do Chinese firms tend to acquire strategic assets in international expansion? Journal of World Business, 44(1), 74-84.

Deng, P., Liu, Y., Gallagher, V. C., \& Wu, X. (2018). International strategies of emerging market multinationals: A dynamic capabilities perspective. Journal of Management \& Organization Doi:doi.org/10.1017/jmo.2017.76.

Godinho, M. M., \& Ferreira, V. (2012). Analyzing the evidence of an IPR take-off in China and India. Research Policy, 41(3), 499-511.

Griffith, D. A., Zeybek, A. Y., \& O Brien, M. (2001). Knowledge transfer as a means for relationship development: a Kazakhstanforeign international joint venture illustration. Journal of International Marketing, 9(2), 1-18.

Guo, D., Guo, Y., \& Jiang, K. (2016). Government-subsidized R\&D and firm innovation: Evidence from China. Research Policy, 45(6), 1129-1144.

Hobday, M. (1995). East Asian latecomer firms: Learning the technology of electronics. World Development, 23(7), 1171-1193.

Huang, K. G., Geng, X., \& Wang, H. (2017). Institutional regime shift in intellectual property rights and innovation strategies of firms in China. Organization Science, 28(2), 355-377.

Jiang, S.江诗松, Gong, L.龚丽敏, \& Wei, J.魏江. (2011). 转型经济背景下后发企业的能力追赶: 一个共演模型: 以吉利集团 为例 (Capability catch-up of latecomer firms in transitional economies. A coevolution model in the case of Geely). 管理世界 (Management World), 2011(04), 122-137.

Kafouros, M., Wang, C., Piperopoulos, P., \& Zhang, M. (2015). Academic collaborations and firm innovation performance in China: The role of region-specific institutions. Research Policy, 44(3), 803-817.

Khanna, T., \& Palepu, K. (1997). Why focused strategies may be wrong for emerging markets. Harvard Business Review, 75(4), 41-48.

Kim, L. (1997). Imitation to innovation: The dynamics of Korea's technological learning. Boston: Harvard Business School Press.

Kim, L. (1998). Crisis construction and organizational learning: Capability building in catching-up at Hyundai motor. Organization Science, 9(4), 506-521.

Landau, C., Karna, A., Richter, A., Uhlenbruck, K. (2016) Institutional leverage capability: creating and using institutional advantages for internationalization. Global Strategy Journal, 6 (1), 50-68.

Landini, F., Lee, K., \& Malerba, F. (2017). A history-friendly model of the successive changes in industrial leadership and the catch-up by latecomers. Research Policy, 46(2), 431-446.

Lee, K. (2005). Making a technological catch-up: Barriers and opportunities. Asian Journal of Technology Innovation, 13(2), 97-131.

Lee, K., Hahn, D., \& Lin, J. (2002). Is China following the east Asian model? The China Review, 2(1), 85-120.

Lee, K., \& Lim, C. (2001). Technological regimes, catching-up and leapfrogging: Findings from the Korean industries. Research Policy, 30, 459-483.

Lee, K., \& Malerba, F. (2017a). Theory and empirical evidence of catch-up cycles and changes in industrial leadership. Research Policy, 46(2), 337.

Lee, K., \& Malerba, F. (2017b). Catch-up cycles and changes in industrial leadership: Windows of opportunity and responses of firms and countries in the evolution of sectoral systems. Research Policy, 46(2), 338-351.

Leiponen, A., \& Helfat, C. E. (2010). Innovation objectives, knowledge sources, and the benefits of breadth. Strategic Management Journal, 31(2), 224-236.

Liang, F. H. (2017). Does foreign direct investment improve the productivity of domestic firms? Technology spillovers, industry linkages, and firm capabilities. Research Policy, 46(1), 138-159.

Liu, F., Simon, D. F., Sun, Y., \& Cao, C. (2011). China's innovation policies: Evolution, institutional structure, and trajectory. Research Policy, 40(7), 917-931.

Liu, Y., Lv, D., Ying, Y., Arndt, F., \& Wei, J. (2018). Improvisation for innovation: The contingent role of resource and structural factors in explaining innovation capability. Technovation, 74-75, 32-41.

Liu，Y 刘洋. (2017). 中国式的创新追赶与超越(Chinese firms' Innovation Catch-up). 清华管理评论(Tsinghua Management Review), 2017(8), 88-94.

Liu, Y 刘洋, Wei, J 魏江, Jiang, S江诗松 . (2013). 后发企业如何进行创新追赶?研发网络边界拓展的视角(How do the latecomer firms achieve innovation catch up? A boundary spanning perspective). 管理世界(Management World), 2013(3), 96-111. 
Liu, Y., Ying, Y., \& Wu, X. (2017). Catch-up through collaborative innovation: Evidence from China. Thunderbird International Business Review, 59(4), 533-545.

Luo, Y., Sun, J., Wang, SL. (2011) Emerging economy copycats: capability, environment, and strategy. Academy of Management Perspectives, 25(2), 37-56.

Luo, Y., \& Wang, S. L. (2012). Foreign direct investment strategies by developing country multinationals: A diagnostic model for home country effects. Global Strategy Journal, 2(3), 244-261.

Madhok, A., \& Keyhani, M. (2012). Acquisitions as entrepreneurship: Asymmetries, opportunities, and the internationalization of multinationals from emerging economies. Global Strategy Journal, 2(1), 26-40.

Mahmood, I. P., \& Singh, J. (2003). Technological dynamism in Asia. Research Policy, 32(6), 1031-1054.

Mathews, J. A., \& Cho, D. S. (1999). Combinative capabilities and organizational learning in latecomer firms: The case of the Korean semiconductor industry. Journal of World Business, 34(2), 139-156.

Miller, D. (2003). An asymmetry-based view of advantage: Towards an attainable sustainability. Strategic Management Journal, 24(10), 961-976.

Morrison, A., \& Rabellotti, R. (2017). Gradual catch up and enduring leadership in the global wine industry. Research Policy, $46(2), 417-430$.

Mu, Q., \& Lee, K. (2005). Knowledge diffusion, market segmentation and technological catch-up: The case of the telecommunication industry in China. Research Policy, 34(6), 759-783.

Nam, K. (2015). Compact organizational space and technological catch-up: Comparison of China's three leading automotive groups. Research Policy, 44(1), 258-272.

Peng, M. W. (2003). Institutional transitions and strategic choices. Academy of Management Review, 28(2), 275-296.

Peng, X., \& Liu, Y. (2016). Behind eco-innovation: Managerial environmental awareness and external resource acquisition. Journal of Cleaner Production., 139, 347-360.

Perez, C., \& Soete, L. (1988). Catching up in technology: entry barriers and windows of opportunity. In Dosi et al. (Eds.), Technical Change and Economic Theory (pp. 458-479). London: Pinter Publishers.

Rong, Z., Wu, X., \& Boeing, P. (2017). The effect of institutional ownership on firm innovation: Evidence from Chinese listed firms. Research Policy, 46(9), 1533-1551.

Sheth, J. N. (2011). Impact of emerging markets on marketing: Rethinking existing perspectives and practices. Journal of Marketing, 75(4), 166-182.

Shin, J. (2017). Dynamic catch-up strategy, capability expansion and changing windows of opportunity in the memory industry. Research Policy, 46(2), 404-416.

Vértesy, D. (2017). Preconditions, windows of opportunity and innovation strategies: Successive leadership changes in the regional jet industry. Research Policy, 46(2), 388-403.

Wei, J, 魏江(2002). 企业技术能力论:技术创新的一个新视角(Firm Technology Capability. A new perspective on technological innovation). 北京(Beijing).科学出版社(Science Press).

Wei, J 魏江 \& Liu, Y 刘洋 (2017). 中国企业的非对称创新战略 (Chinese firms' asymmetric innovation strategy). 清华管理评 论(Tsinghua Management Review), 2017(10), 20-26.

Wei, J 魏江, Liu, Y 刘洋, Huang, X黄学, Yang, Y 杨洋, (2017). 非对称创新战略:中国企业的跨越(理论辑)(Asymmetric Innovation Strategy: innovation Globalization of Chinese Firms(Theoretical Volume)). 北京(Beijing):科学出版社(Science Press).

Wei, J., Liu, Y., Jiang, S., \& Zhang, Z. (2016a). Does ownership heterogeneity matter in technological catch ups? Empirical evidence from Chinese SOEs and POEs. International Journal of Technology Management, 72(4), 253-272.

Wei J 魏江, Liu, Y 刘洋, Ying, Y 应瑛, \& Peng, X 彭雪蓉, (2016b). 启发式规则与后发企业追赶战略抉择: 一个探索性研究 (Organizational heuristics and innovation catch-up: An exploratory study). 管理学季刊 (Quarterly Journal of Management), 2016(4), 18-37.

Wei, J 魏江, Pan, Q 潘秋玥 \& Wang, S 王诗翔, (2016c). 制度型市场与技术追赶(Institution-led market and technological catch-up). 中国工业经济(China Industrial Economics), 2016 (09), 93-108.

Wei, J 魏江, \& Wang, S 王诗翔 (2017). 从“反应”到“前摄”：万向在美国的合法性战略演化(1994-2015)( From reaction to proaction: legitimacy strategy evolution of WANXIANG in the United States (1994-2015)). 管理世界(Management World), 2017(08), 136-153.

Wei, J 魏江, Wang, S 王诗翔 \& Yang, Y 杨洋. (2016f). 向谁同构?中国跨国企业海外子公司对制度双元的响应(Which environment to be isomorphism with? Responses of Sino-MNCs' foreign subsidiaries to institutional duality).管理世 界(Management World >), 2016(10), 134-149.

Wei, J 魏江, Wu, A 鸟爱其, Peng, X 彭雪蓉. (2014b). 中国战略管理研究: 情境问题与理论前沿(Chinese strategic management research: context and theoretical frontiers). 管理世界(Management World), 2014(12), 167-171.

Wei, J 魏江, Ying, Y 应瑛, \& Liu, Y 刘洋. (2014a). 研发网络分散化, 组织学习顺序与创新绩效:比较案例研究(The decentralization of the R\&D network, the sequence of the organizational learning and the innovation performance. A multi-case study). 管理世界(Management World),2014 (02): 137-151.

Wei, J 魏江, Ying, Y. 应瑛, \& Pan, Q 潘秋玥. (2016e). 创新全球化:中国企业的跨越(案例辑)(Innovation Globalization of Chinese Firms(Case Volume)), 北京(Beijing):科学出版社(Science Press).

Wei, J., Zhou, M., Greeven, M., \& Qu, H. (2016g). Economic governance, dual networks and innovative learning in five Chinese industrial clusters. Asia Pacific Journal of Management, 33(4), 1037-1074.

Wu, A., \& Wei, J. (2013). Effects of geographic search on product innovation in industrial cluster firms in China. Management and Organization Review, 9(3), 465-488.

Wu, J. (2012). Technological collaboration in product innovation: The role of market competition and sectoral technological intensity. Research Policy, 41(2), 489-496.

Xiao, Y., Tylecote, A., \& Liu, J. (2013). Why not greater catch-up by Chinese firms? The impact of IPR, corporate governance and technology intensity on late-comer strategies. Research Policy, 42(3), 749-764.

Zeschky, M., Widenmayer, B., \& Gassmann, O. (2011). Frugal innovation in emerging markets. Research-Technology Management, 54(4), 38-45.

Zeschky, M. B., Winterhalter, S., \& Gassmann, O. (2014). From cost to frugal and reverse innovation: Mapping the field and implications for global competitiveness. Research Technology Management, 57(4), 20-27.

Zhou, K. Z., Gao, G. Y., \& Zhao, H. (2017). State ownership and firm innovation in China: An integrated view of institutional and efficiency logics. Administrative Science Quarterly, 62(2), 375-404. 